S6 Table. Associations of BMI with cancer mortality according to Cr levels

\begin{tabular}{|c|c|c|c|c|c|}
\hline \multicolumn{6}{|c|}{ Cancer death } \\
\hline \multirow[t]{2}{*}{ Male } & \multirow[b]{2}{*}{ Tertile of $\mathrm{sCr}$} & \multicolumn{4}{|c|}{ Categories of BMI $\left(\mathrm{kg} / \mathrm{m}^{2}\right)$} \\
\hline & & $<18.5$ & 18.5-24.9 & $25.0-29.9$ & $\geq \mathbf{3 0 . 0}$ \\
\hline \multirow{3}{*}{ Unadjusted } & Lowest & $3.09(2.45-3.91)^{\mathrm{a}}$ & $2.17(1.76-2.67)^{\mathrm{a}}$ & $1.32(0.81-2.16)$ & 0.00 \\
\hline & Middle & $1.21(0.83-1.76)$ & Reference & $0.97(0.60-1.56)$ & $0.41(0.06-2.92)$ \\
\hline & Highest & $0.62(0.32-1.23)$ & $0.25(0.17-0.36)^{\mathrm{a}}$ & $0.27(0.13-0.54)^{\mathrm{a}}$ & $0.18(0.03-1.29)$ \\
\hline \multirow{3}{*}{ Model 1} & Lowest & $2.48(1.96-3.15)^{\mathrm{a}}$ & $1.86(1.50-2.29)^{\mathrm{a}}$ & $1.34(0.82-2.19)$ & 0.00 \\
\hline & Middle & $1.22(0.83-1.77)$ & Reference & $1.07(0.66-1.72)$ & $0.62(0.09-4.48)$ \\
\hline & Highest & $0.90(0.46-1.78)$ & $0.32(0.22-0.47)^{\mathrm{a}}$ & $0.38(0.19-0.78)^{\mathrm{b}}$ & $0.34(0.05-2.47)$ \\
\hline \multirow{3}{*}{ Model 2} & Lowest & $2.51(1.98-3.19)^{\mathrm{a}}$ & $1.94(1.56-2.40)^{\mathrm{a}}$ & $1.45(0.88-2.38)$ & 0.00 \\
\hline & Middle & $1.17(0.80-1.71)$ & Reference & $1.11(0.68-1.79)$ & $0.66(0.09-4.78)$ \\
\hline & Highest & $0.85(0.43-1.68)$ & $0.31(0.21-0.46)^{\mathrm{a}}$ & $0.39(0.19-0.79)^{\mathrm{b}}$ & $0.35(0.05-2.55)$ \\
\hline \multirow{3}{*}{ Model 3} & Lowest & $1.51(1.17-1.94)^{b}$ & $1.39(1.12-1.73)^{\mathrm{b}}$ & $1.11(0.67-1.83)$ & 0.00 \\
\hline & Middle & $1.16(0.79-1.69)$ & Reference & $1.08(0.67-1.75)$ & $0.61(0.09-4.41)$ \\
\hline & Highest & $0.99(0.50-1.96)$ & $0.36(0.24-0.52)^{\mathrm{a}}$ & $0.43(0.21-0.89)^{\mathrm{c}}$ & $0.38(0.05-2.76)$ \\
\hline
\end{tabular}

\title{
Cancer death
}

Female Categories of BMI $\left(\mathrm{kg} / \mathrm{m}^{2}\right)$

\begin{tabular}{|c|c|c|c|c|c|}
\hline & Tertile of $\mathrm{sCr}$ & $<18.5$ & $18.5-24.9$ & 25.0-29.9 & $\geq 30.0$ \\
\hline \multirow{3}{*}{ Unadjusted } & Lowest & $3.02(2.01-4.54)^{\mathrm{a}}$ & $2.52(1.69-3.76)^{\mathrm{a}}$ & $1.53(0.68-3.45)$ & 0.00 \\
\hline & Middle & $1.16(0.66-2.03)$ & Reference & $0.85(0.33-2.17)$ & $2.72(0.83-8.88)$ \\
\hline & Highest & $0.46(0.19-1.09)$ & $0.46(0.26-0.82)^{b}$ & $0.42(0.13-1.36)$ & $0.61(0.08-4.49)$ \\
\hline \multirow{3}{*}{ Model 1} & west & $2.50(1.65-3.78)^{\mathrm{a}}$ & $2.17(1.45-3.25)^{\mathrm{a}}$ & $1.48(0.66-3.34)$ & 0.00 \\
\hline & Middle & $1.20(0.69-2.11)$ & Reference & $0.89(0.35-2.28)$ & $3.29(1.00-10.80)^{\mathrm{c}}$ \\
\hline & Highest & $0.64(0.27-1.54)$ & $0.62(0.35-1.10)$ & $0.55(0.17-1.81)$ & $0.95(0.13-6.99)$ \\
\hline \multirow{3}{*}{ Model 2} & Lowest & $2.51(1.66-3.80)^{\mathrm{a}}$ & $2.24(1.49-3.37)^{\mathrm{a}}$ & $1.57(0.69-3.57)$ & 0.00 \\
\hline & Middle & $1.17(0.67-2.06)$ & Reference & $0.92(0.36-2.36)$ & $3.47(1.05-11.43)^{\mathrm{c}}$ \\
\hline & Highest & $0.62(0.26-1.50)$ & $0.61(0.34-1.09)$ & $0.56(0.17-1.84)$ & $0.99(0.13-7.26)$ \\
\hline \multirow{3}{*}{ Model 3} & Lowest & $1.72(1.12-2.64)^{\mathrm{c}}$ & $1.67(1.10-2.54)^{\mathrm{c}}$ & $1.22(0.53-2.81)$ & 0.00 \\
\hline & Middle & $1.18(0.67-2.09)$ & Reference & $0.85(0.33-2.18)$ & $3.00(0.91-9.92)$ \\
\hline & Highest & $0.71(0.29-1.71)$ & $0.65(0.36-1.16)$ & $0.55(0.17-1.81)$ & $0.90(0.12-6.63)$ \\
\hline
\end{tabular}

Data are expressed as odds ratio (95\% confidence interval) compared to the reference group of BMI 18.5-24.9 with middle tertile of sCr. Model 1: adjusted for age

Model 2: adjusted for age, dialysis vintage, diabetes mellitus

Model 3: adjusted for age, dialysis vintage, diabetes mellitus, serum albumin, phosphorus, C-reactive protein , Kt/V

${ }^{\mathrm{a}} \mathrm{p}<0.001,{ }^{\mathrm{b}} \mathrm{p}<0.01,{ }^{\mathrm{c}} \mathrm{p}<0.05$ Abbreviation: BMI, body mass index; $\mathrm{sCr}$, serum creatinine 